Pacific Northwest

National Laboratory

Operated by Battelle for the

U.S. Department of Energy

\section{Statement of Work for Drilling Four CERCLA Groundwater Monitoring Wells During Fiscal Year 2006, 300-FF-5 Operable Unit}

B. A. Williams

October 2005

Prepared for the U.S. Department of Energy under Contract DE-AC05-76RL01830 


\title{
DISCLAIMER
}

This report was prepared as an account of work sponsored by an agency of the United States Government. Reference herein to any specific commercial product, process, or service by trade name, trademark, manufacturer, or otherwise does not necessarily constitute or imply its endorsement, recommendation, or favoring by the United States Government or any agency thereof, or Battelle Memorial Institute.

\author{
PACIFIC NORTHWEST NATIONAL LABORATORY \\ operated by \\ BATTELLE \\ for the \\ UNITED STATES DEPARTMENT OF ENERGY \\ under Contract DE-AC05-76RL01830
}

\begin{abstract}
Printed in the United States of America
Available to DOE and DOE contractors from the

Office of Scientific and Technical Information, P.O. Box 62, Oak Ridge, TN 37831;

prices available from (615) 576-8401.

Available to the public from the National Technical Information Service,

U.S. Department of Commerce, 5285 Port Royal Rd., Springfield, VA 22161
\end{abstract}

This document was printed on recycled paper. 
PNNL-15308, Rev. 1

Statement of Work for

Drilling Four CERCLA Groundwater

Monitoring Wells During Fiscal Year 2006, 300-FF-5 Operable Unit

B. A. Williams

October 2005

Prepared for

the U.S. Department of Energy

under Contract DE-AC05-76RL01830

Pacific Northwest National Laboratory

Richland, Washington 99352 


\section{Summary}

Pacific Northwest National Laboratory, the U.S. Department of Energy (DOE), and the Environmental Protection Agency (EPA) have agreed that four characterization wells shall be installed in the 300-FF-5 Operable Unit and these wells will be proposed for inclusion into the Hanford Federal Facility Agreement and Consent Order (Tri-Party Agreement [TPA]) Milestone M-24-57. These wells are also documented in the 300-FF-5 Limited Field Investigation Plan. This document contains the statement of work required to drill, characterize, and construct the proposed groundwater monitoring wells during FY 2006. 


\section{Contents}

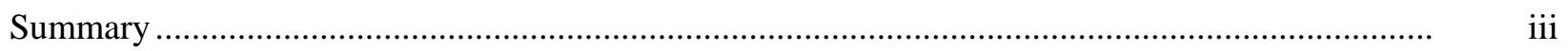

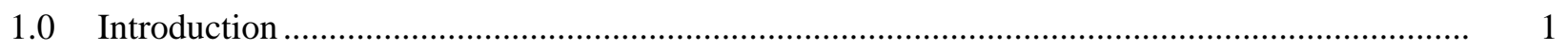

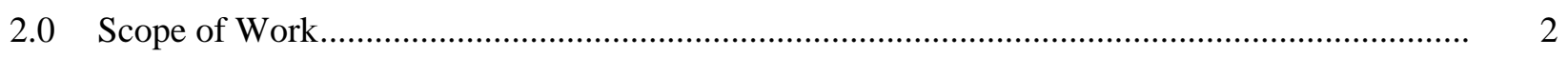

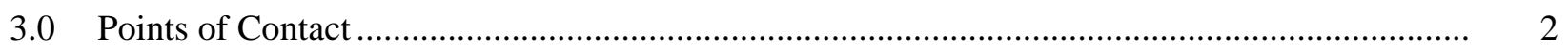

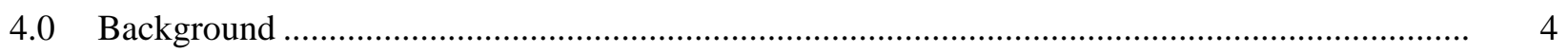

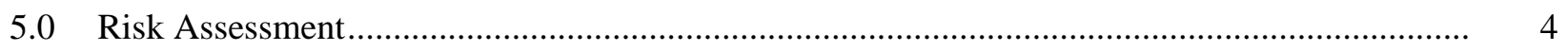

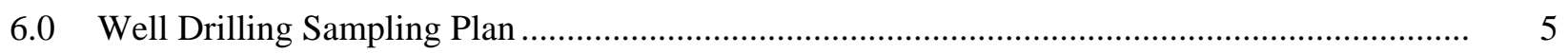

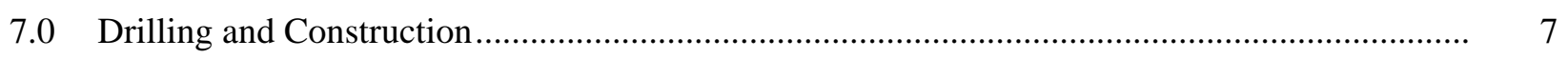

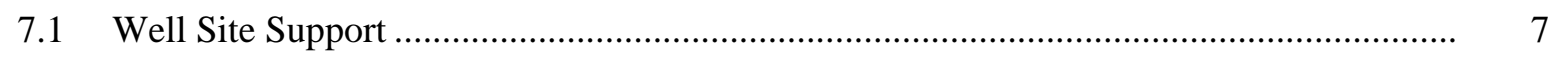

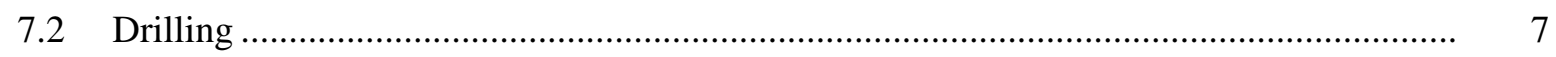

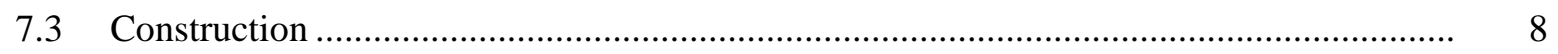

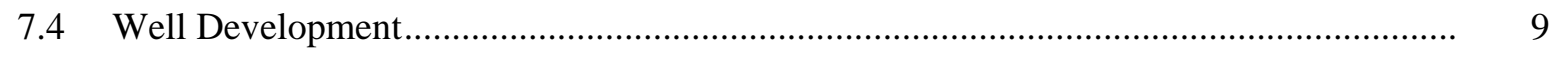

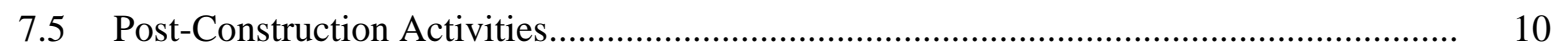

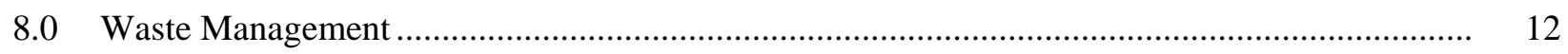

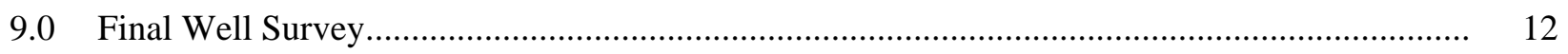

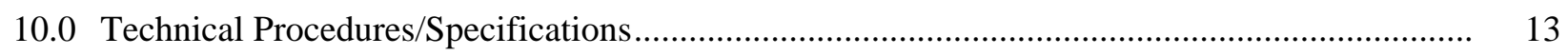

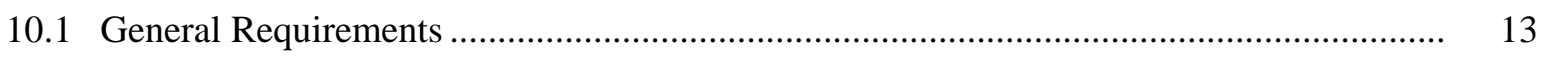

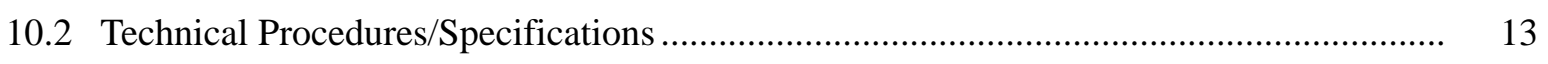

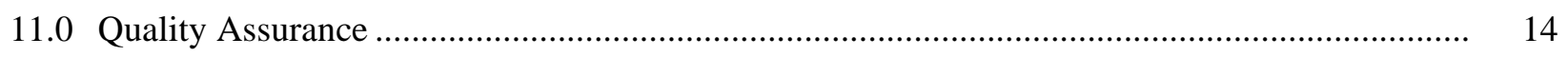

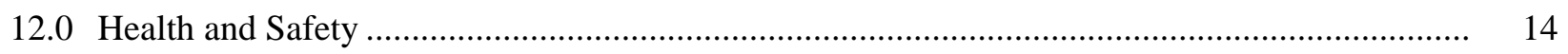

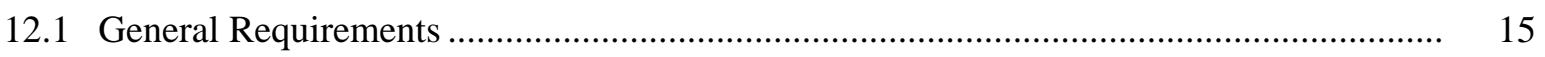

12.2 Radiological and Chemical Hazard Evaluation............................................................. 15

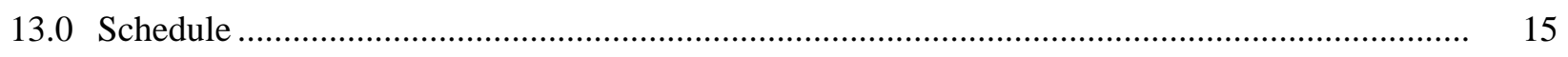

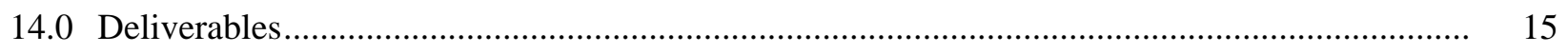

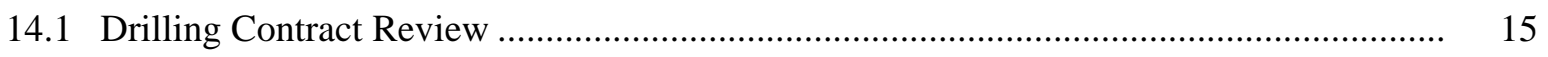

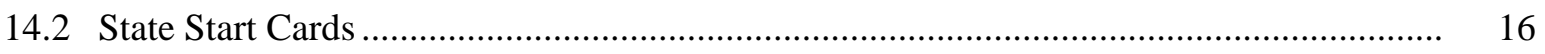

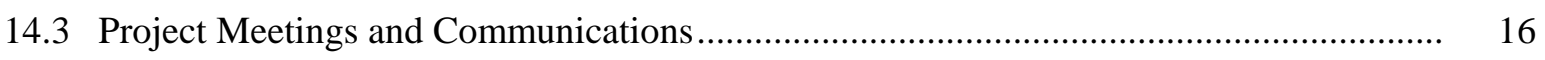

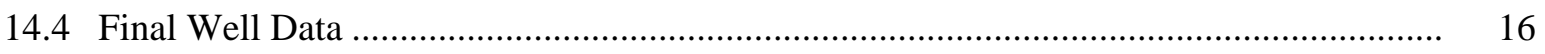

14.5 Project Completion/Final Well Acceptance ................................................................. 16

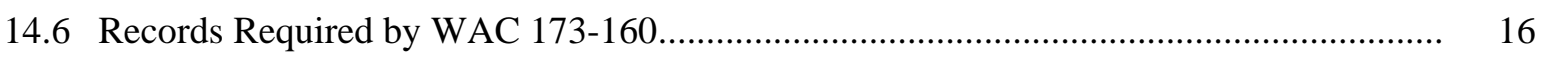

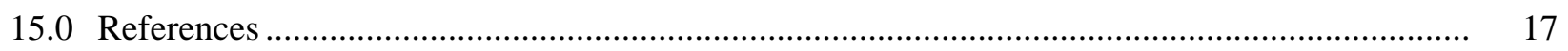


Appendix A - Well Data Sheet and Well Staking Plat ................................................................. A.1

Appendix B - Field Geologist Qualifications ........................................................................ B. B

\section{Figures}

1 Location Map of the Four Characterization Wells, 300-FF-5 Operable Unit............................... 3

2 Example Diagram of a 6-Inch-Diameter Support Plate for the Sampling Pump System .............. 11 


\subsection{Introduction}

This statement of work (SOW) provides the information required to drill, characterize, and construct two deep characterization wells and two shallow characterization wells during fiscal year (FY) 2006 as identified and defined by Pacific Northwest National Laboratory (PNNL), the U.S. Department of Energy (DOE), and the U.S. Environmental Protection Agency (EPA). All four wells will be completed as shallow monitoring wells unless otherwise specified below.

DOE has authorized PNNL to proceed with the planning and installation of four characterization wells in support of the 300-FF-5 Operable Unit (OU) limited field investigation (LFI). These new wells are being installed to investigate the location and extent of subsurface uranium sources(s) that persist within the 300-FF-5 OU. The completed well network will be used to also support future treatability testing technologies for the 300-FF-5 OU. The new wells will be proposed for inclusion into the TriParty Agreement (Ecology et al. 1989, as amended) Milestone M-24-57.

This SOW provides the specifications for drilling, characterization, and installation of the wells to Fluor Hanford, Inc. (FHI), the DOE drilling contractor for the Hanford Site.

PNNL is responsible for determining needs, locations, and design requirements for wells in compliance with the Comprehensive Environmental Response, Compensation, and Liability Act (CERCLA) to meet the 300-FF-5 OU cleanup objectives. FHI is responsible for estimating cost, procuring equipment and materials, maintaining drilling schedule (as concurred with by PNNL to ensure meeting technical and logistical objectives), and constructing the wells. FHI also is responsible for preparing the Washington State-required drilling Start Cards (Washington Administrative Code [WAC] 173-160), pre-job planning, wellsite duties (e.g., geologist, samplers), waste management, and wellsite health and safety.

In addition, FHI is responsible for obtaining the necessary permits for well construction, such as excavation permits, radiation work permits, and cultural resource reviews Further, FHI is responsible for conducting the project in accordance with DOE-approved and WAC-compliant technical procedures and technical drilling specifications. Site cleanup is also the responsibility of FHI. PNNL, in conjunction with FHI, shall accept the wells as sample-ready to satisfy the conditions of this SOW.

Well drilling and construction must adhere to the requirements in WAC 173-160. For these wells, specific technical requirements are provided in the 300-FF-5 OU LFI plan (DOE 2005a).

The technical aspects defined in the 300-FF-5 LFI plan for the new FY 2006 wells are included in this SOW and Appendix A. The quality assurance and quality control aspects of the LFI plan are included in the project quality assurance plan (Walker 2005). Together, these two documents constitute the sampling and analysis plan for the new wells.

English units are used in this report (except for well surveys) because that is the system of units used by drillers to measure and report depths and well construction details. To convert feet to meters, multiply by 0.3048 ; to convert inches to centimeters, multiply by 2.54 . 


\subsection{Scope of Work}

This document describes requirements for the installation of four CERCLA characterization wells. The wells are located within the 300 Area, in the southeastern portion of the Hanford Site (Figure 1). The four characterization wells shall be sample-ready by January 24, 2006.

This SOW and the Well Data Sheet and Staking Plat (Appendix A) contain the drilling, sampling, and completion requirements for the new wells. This SOW and the Well Data Sheet are intended as guidelines for FHI planning purposes. Any questions or discrepancies concerning the scope of this work should be reviewed with the PNNL point of contact prior to start of the work. The Staking Plat provides the locations for the proposed new wells. Specific directions to the locations are provided in the Well Data Sheet. PNNL in conjunction with FHI shall stake the wells after receipt of this SOW.

The characterization requirements defined in the Well Data Sheet are intended to meet information needs for the CERCLA 300-FF-5 OU LFI. The information needs support the remedial investigation/ focused feasibility study that is in progress, which includes a new groundwater flow and transport model (DOE 2005b). Additional data collection needs and/or changes to the Well Data Sheet will be determined jointly by FHI, PNNL, and the DOE Richland Operations Office (DOE-RL), and documented in an addendum to this SOW. Costs for additional work not specified in the contractor's original cost estimate will be approved prior to start of work by PNNL. The work will be performed when PNNL confirms that the required funding is available.

\subsection{Points of Contact}

The points of contact (POCs) for this work are as follows:

\begin{tabular}{llc}
\multicolumn{1}{c}{ Name } & \multicolumn{1}{c}{ Role } & \multicolumn{1}{c}{ Phone } \\
Mr. B. A. Williams & POC - PNNL & 509-372-3799 \\
Dr. D. G. Horton & Alternate POC - PNNL & 509-376-6868 \\
Mr. C. S. Wright & POC - FHI & 509-373-3994
\end{tabular}




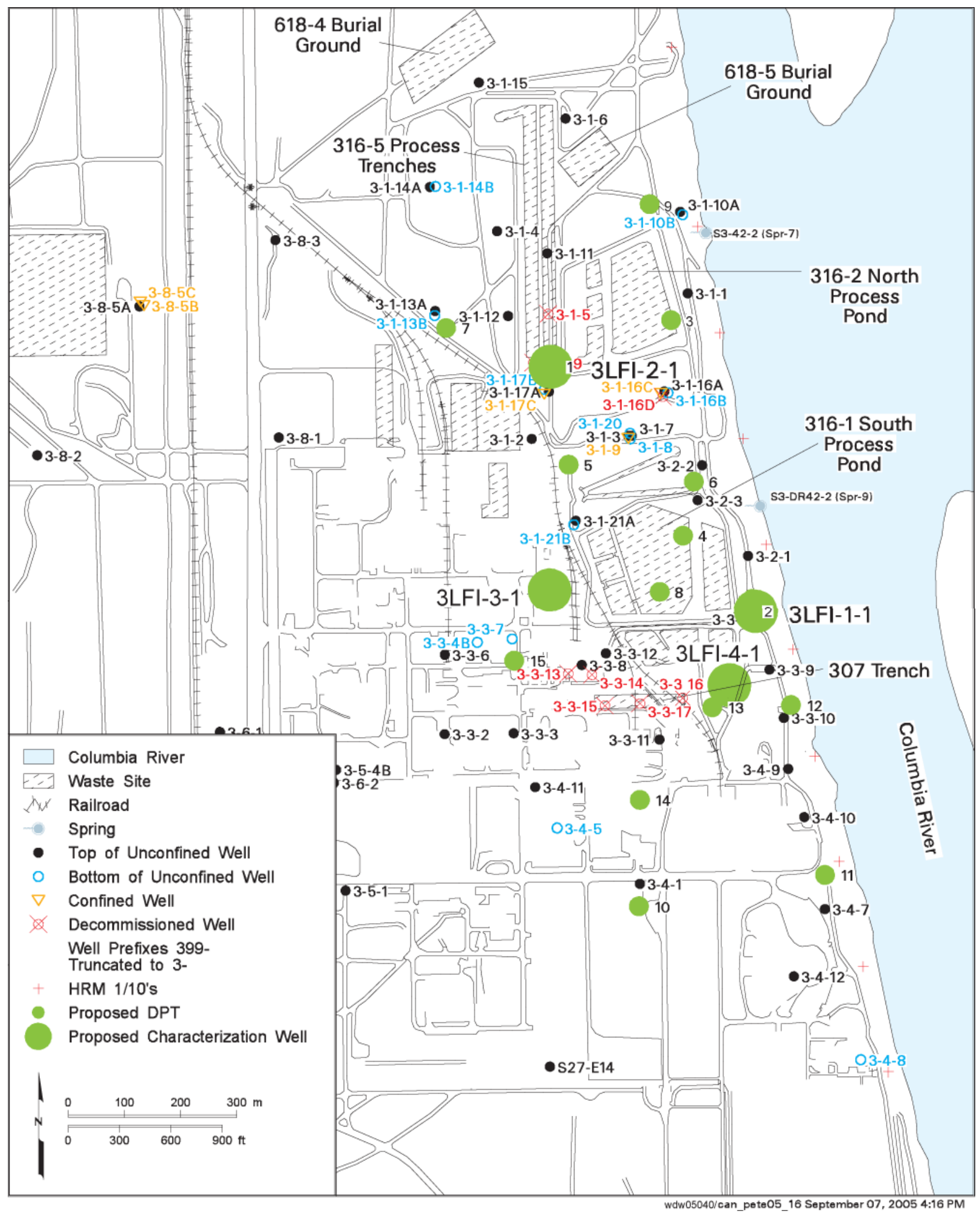

Figure 1. Location Map of the Four Characterization Wells, 300-FF-5 Operable Unit 


\subsection{Background}

DOE Orders require the Hanford Groundwater Performance Assessment Project to maintain groundwater-monitoring compliance with applicable CERCLA and Resource Conservation and Recovery Act (RCRA) regulations (WAC 173-303-400 and WAC 173-303-600).

In 1996, a record of decision (EPA 1996) was issued for the 300-FF-5 Operable Unit on the Hanford Site in southeastern Washington State. The record of decision identified interim actions for remediation of the uranium contaminant plume beneath the site:

- continued groundwater monitoring to determine how contaminant conditions may change with time - institutional controls to limit the use of groundwater

These interim actions have determined that uranium concentrations in the groundwater plume have been declining but persist at concentrations above the drinking water standard (remediation goal). Therefore, reevaluation of the remedy for uranium contamination is necessary because the rate of decrease in uranium concentrations differs significantly from the rate of decrease expected and used as a basis for the remedy selection in the current record of decision.

The re-evaluation of the remedy for uranium in the groundwater will be documented in the Phase III Feasibility Study. An LFI is being conducted as part of the feasibility study to reduce uncertainties in two aspects of the conceptual model for the uranium plume: 1) the distribution and amount of uranium in the vadose zone (especially in the interface between unsaturated and saturated conditions- the river-induced capillary fringe zone) where water quality standards are exceeded and 2) the geochemical characteristics associated with uranium in the vadose zone and aquifer, including aquifer sediment. Continuous core samples will be obtained at four representative sites, followed by a direct-push boring program for obtaining downhole radiological data. These activities will address the two aspects above. The scope of this SOW pertains to only the drilling and characterization at the four characterization well sites.

\subsection{Risk Assessment}

FHI shall evaluate and assess the proposed well locations for the potential of encountering radiological contamination prior to drilling. The risk assessment shall be used to develop the site health and safety plans and radiological monitoring requirements. Geologic and drilling observations from nearby wells provide good sources for predicting expected subsurface conditions. FHI personnel may examine available information near the well locations that includes lithologic and geophysical logs, drilling observations from nearby wells, pipeline maps, and Waste Information Data System summary reports of nearby waste sites.

PNNL does not take responsibility for any actions, impacts, or issues related to activities resulting from use of this information. 


\subsection{Well Drilling Sampling Plan}

Appendix A provides the Well Data Sheet and Staking Plat for the new wells. Information includes estimated depths to water, estimated drill depths, characterization and sampling requirements, and well design requirements. All depths are estimates to be used for planning purposes; required depths may change and should be verified during drilling by the field geologist. PNNL requires a qualified field geologist to collect samples and provide a detailed geologic description of the sediments encountered in

each borehole drilled. The geologist's qualifications are specified in Appendix B. The intent is to have expertise to accurately identify geologic features that are somewhat unique to the Hanford Site (e.g., clastic dikes, paleosols) and have knowledge of the local lithologic changes.

Depending on the drilling technique and the availability of drill cuttings, samples for geologic descriptions shall be collected at intervals no greater than $5 \mathrm{ft}$ (beginning at ground surface) and at changes in lithology. Representative samples from each 5-ft interval shall be stored in 1-pt to 1-qt size, (dependent on grain size) containers with lids. Archive samples shall be collected every $5 \mathrm{ft}$ and placed in individual 1-pt wide-mouth glass jars. In addition, continuous intact core samples are required from all four of the characterization boreholes. If there is not enough sample material for the grab samples, due to the coring operation or for any other reason, the geologist will note the reason why no sample was recovered in the borehole geology log. Specifications for core sample collection, packaging, and labeling are provided below.

Archive samples also shall be collected where unusual or anomalous hydrogeologic conditions exist as determined by the field geologist (e.g., anomalous lithology, clastic dikes, anomalous moisture content, volcanic ash). FHI shall provide a radiological field screen/release of all samples prior to transfer to PNNL. In the event that contaminated sediments or groundwater are encountered during drilling, the PNNL POC will be notified and a determination made by PNNL and FHI whether additional samples (and how many) are required. FHI shall provide all requested samples to the PNNL POC or designee, who shall be responsible for the samples after transfer. Chain-of-custody is not required for archive samples but will be required for continuous core and groundwater samples. FHI shall provide pint-size glass Mason sampling jars with screw-top lids, and any related sampling equipment.

The boreholes shall be drilled with a sonic drilling method that will allow collection of continuous intact sediment sample(s) (i.e., whole core) that are representative of the subsurface sediments (i.e., from the ground surface to total depth). This sampling shall continue as far as practicable or until core refusal. If core sampling cannot be achieved as specified, the FHI POC will contact the PNNL POC (prior to any decisions to stop coring) to develop an alternative sampling plan. Cores are to be collected and contained in clean, new Lexan ${ }^{\circledR}$ liners with a minimum length of $1 \mathrm{ft}$. The diameter of the cores shall be as large as possible; preference is for 6 in. or larger, but not larger than 12 in. in diameter. End caps, stuffing material (as necessary to fill void space), and sealing tape are required to contain the sample from leaking, crumbling/breaking, or becoming contaminated. Each sample container is to be labeled with well number and depth interval sampled. The core liners are not to be opened in the field. Core samples shall be stored onsite in coolers with frozen blue ice. The PNNL POC will be notified when the coolers are full and ready for transfer off the drill site. Chain-of-custody forms shall accompany all continuous core samples off the drill site. PNNL will provide the coolers for packaging core samples. FHI, or the drilling 
contractor, shall provide the specified Lexan liners, end caps, aluminum foil (stuffing), and sealing tape for collection and packaging of the core samples.

Spectral gamma and neutron moisture (vadose zone) borehole logs shall be completed in the drilled boreholes. The purposes of the logging are to 1) provide data for locating and quantifying manmade uranium, 2) provide data to support stratigraphic correlation, 3) provide baseline geophysical well logs, 4) identify potential fine-grained and moisture-bearing intervals, and 5) assist in defining the screen interval. The boreholes shall not be drilled in a way that precludes meaningful geophysical logs-for example, if possible, logging should be completed in a single cased borehole and before downsizing drill casing. Any deviations from these requirements shall be reviewed and approved by PNNL and FHI staff prior to proceeding with geophysical logging. Wireline logging will be done by Stoller, Inc. FHI or the drilling contractor shall be responsible for contracting this work and for notifying the subcontractor when its service is required. FHI also will provide PNNL and Stoller (the geophysical logging contractor) with at least a 24-hour notification before the anticipated logging depth is reached and will notify the logging personnel when logging is required. The geophysical logging will require assistance from the driller to clear the boreholes for logging tool access.

Depth-discrete water samples shall be collected from the boreholes during drilling beneath the water table. A total of about 30 depth-discrete groundwater samples will be collected during drilling of the four characterization wells. Approximately 10 depth-discrete groundwater samples will be recovered during drilling in each of the two deep characterization wells and 5 depth-discrete groundwater samples will be recovered during drilling in each of the two shallow characterization wells.. PNNL shall provide the sample bottle sets (and/or containers) to FHI prior to well startup.

Depth-discrete slug testing also will be completed in the four characterization boreholes at three to four intervals per borehole. Details for slug testing are provided in Appendix A. FHI and/or the drilling contractor shall assist with the test setup by cleaning the borehole of cuttings; removing drill string; installing test screen, packer, and transducers; and providing assistance as necessary during the testing. Depth-discrete slug tests shall be performed following the depth-discrete water sampling if scheduled at the same depth interval. The actual slug tests will be coordinated and performed by a PNNL hydrogeologist.

FHI shall provide 24-hour notice to the PNNL POC prior to reaching all specified groundwater sampling and slug testing depths. FHI or its contractor shall provide the temporary screen, casing, slug rods or pressurized gas, and, as necessary, the wellhead manifold. PNNL shall provide the data loggers and transducers.

A borehole deviation survey, using a downhole gyroscope, shall be performed by others in the wells following final well development and before the permanent pumps are installed. FHI or the drilling contractor shall be responsible for contracting this work and for notifying the subcontractor when its service is required. This survey is intended to provide information required to calculate the amount, if any, of borehole deviation from vertical to allow accurate measurement of the water-table elevation. 


\subsection{Drilling and Construction}

\subsection{Well Site Support}

FHI or its contractor will be responsible for pre-job preparations and field support for drilling, characterization, well completion, and well development. FHI will provide oversight to the contracted drilling crew and will have responsibility for directing and coordinating technical field activities to ensure that the wells are drilled, sampled, and constructed in an efficient and timely manner and meet the requirements specified in this SOW. FHI also will coordinate sediment coring and transfer, depthdiscrete groundwater and aquifer testing, geophysical logging, and borehole deviation surveys. Any specially requested sampling will be reviewed with the FHI POC prior to approval.

FHI must notify and obtain concurrence from the PNNL POC or project scientist prior to proceeding with any work activities that deviate from the original requirements and/or defined workscope and schedule. As required by this SOW, the FH POC will coordinate with the field geologist and PNNL POC or project scientist prior to any decisions needed for core sampling, water sampling, and slug testing and for notification of an unanticipated event (e.g., perched water, unexpected change in lithology, contamination). FHI shall notify the geophysics contractor, borehole deviation survey technician, sampling personnel, and the PNNL POC 24 hours prior to when their support is required at a well.

FHI will communicate daily (by electronic mail or in person) with the PNNL POC and provide a status of well installation activities. FHI is responsible for documenting and verifying well construction techniques and materials in order to produce fitness-for-use documentation for final acceptance of the well and as required for the State Well Record.

\subsection{Drilling}

The new wells are to be drilled and constructed as resource protection wells as defined in WAC 173-160. The new wells are to be installed at the locations provided in the Well Data Sheet attached as Appendix A. The PNNL POC and the FHI POC will have jointly staked the well locations prior to commencement of this FY 2006 drilling contract. FHI is responsible for subsurface surveys, as necessary, to confirm that subsurface obstacles do not exist.

If necessary, the staked well location may be moved up to $50 \mathrm{ft}$ to avoid subsurface obstacles. Notification will be provided to the PNNL POC if the stake is moved, and PNNL concurrence is needed to confirm all new well locations.

FHI or its drilling contractor shall be responsible for complying with well drilling and construction criteria defined in WAC 173-160 and shall follow DOE-approved work procedures. The Well Data Sheet (Appendix A) supplements the WAC 173-160 requirements by providing specific requirements necessary to fulfill the sampling and analysis plan. The boreholes shall be drilled as close to vertical as possible. The PNNL POC shall be notified when the water table is encountered and at total depth, prior to depthdiscrete water sampling and aquifer testing, prior to geophysical logging, and before well construction. The quantity of potable water, foaming agents, or other fluids used in drilling, completion, and development shall be minimized and recorded. Drilling footages shall be recorded daily for each well. 
All downhole equipment (including submersible sampling pumps, gyroscope, and core samplers) shall be steam-cleaned (i.e., high pressure and temperature) or decontaminated to minimize contaminants. When requested by either the field geologist or the PNNL POC (as required in the Well Data Sheet), the well shall be made clear of all tools to permit measurements and/or collect samples. The final actual total depth of the well will be determined in accordance with the Well Data Sheet by the field geologist and may change depending on the hydrogeologic conditions encountered.

Perched water is not expected in this area. If perched water is encountered, the PNNL POC will be notified, and the perched water will be sampled.

\subsection{Construction}

The wells shall be constructed in accordance with the WAC 173-160 requirements and consistent with Hanford Site well construction standards. The wells shall be constructed with stainless steel casing and stainless steel screen with appropriate sand pack (100\% silica sand) as specified in the Well Data Sheet. The placement of well seals and riser casings is at the discretion of FHI with the exception of any seals specified herein and in the Well Data Sheet and shall meet the minimum requirements of WAC 173-160. The FHI POC shall contact the PNNL POC to resolve any unrecognized or unanticipated well design discrepancies prior to drilling the borehole.

Stainless steel screens and borehole casing, 8 in. in diameter, will be required for completing the four wells to support future treatability testing. The wells also shall be designed to allow for water level measurements (either E-tape or steel tape) to be taken without removal of dedicated sampling pump and equipment. Screens will be stainless steel continuous wire wrap with a slot size and filter pack of either 20-slot screen and 10- to 20-mesh sand or as determined based on standard sieve analysis of sediment samples from the borehole interval to be screened. Each well screen will be a minimum $15 \mathrm{ft}$ in length or as determined by the project scientist (see Appendix A). Appendix A provides well design details.

Annular seals (bentonite) shall be completed in such a manner as to prohibit the seal from leaking or migrating into the saturated zone and screened interval.

Well completion will not begin until the screen slot size and filter pack size are confirmed by the field samples. All sieving shall follow PNNL ${ }^{(a)}$ or equivalent FHI procedures. If field sieve analyses dictate a screen slot and filter pack of different size than that specified in this SOW and Appendix A, the PNNL POC shall confirm the alternative screen and filter pack specification.

A 4-ft by 4-ft concrete pad will be installed around the permanent casing and a protective casing. Four steel posts and a brass identification marker will be installed in the pad. The protective casing and locking cap shall be nominally 2 in. larger in diameter than the permanent casing and made of stainless steel. A locking cap shall provide not less than 6-in. clearance above the landing plate.

(a) Pacific Northwest National Laboratory. 1999. Procedures for Groundwater Investigations. PNL-MA-567, Hanford Site Groundwater Monitoring Project, Pacific Northwest National Laboratory, Richland, Washington. 
The final well stickup (protective casing) should be not more than $3 \mathrm{ft}$ above ground to accommodate sampling crews. The permanent stainless steel casing shall have a stickup of between $1.75 \mathrm{ft}$ and $2 \mathrm{ft}$ above ground surface. Appendix A specifies the approximate well depths, screen lengths, and anticipated water depth for the wells.

The well numbers and well names will be stenciled on the protective casing. The drilling contractor is responsible for installing (and labeling) the brass cap into the concrete surface pad.

\subsection{Well Development}

Well development shall consist of surging and pumping to clean the disturbed zone surrounding the borehole, recover drilling fluids and cuttings, and maximize well production. Well development shall be conducted in two steps: 1) predevelopment during well construction to settle the sand pack behind the screen and flush the surrounding formation of fines and cuttings; and 2) final development after the well is constructed, to improve aquifer communication between the surrounding aquifer and the well and remove residual fines and drill cuttings. Final well development criteria are defined below.

To settle the sand pack during predevelopment, the surge block technique will be used to aggressively surge the well at intervals not to exceed $3 \mathrm{ft}$ of sand placement at a time. As needed, a submersible pump also may be used as an effective surge block that pumps during the surging action, thus effectively working as a vacuum to remove the fine sediments immediately, which facilitates a more uniform development along the well screen and improves the effectiveness of the final well development.

During final well development, the development pump intake shall be placed at no less than two equally spaced intervals along the screen to adequately develop the entire 15 - $f$ sample interval. The first zone to be developed will be the lowest $10 \mathrm{ft}$. The development pump intake shall be placed in the lower 10 to $15 \mathrm{ft}$ of the screen. The pumping rate shall be incrementally increased up to $20 \mathrm{gpm}$, assuming excessive drawdown does not become a problem. The second interval (upper 5 to $10 \mathrm{ft}$ of the screen) shall be pumped at a lower rate (i.e., 3 to 5 gpm) and gradually increased to avoid drawdown-induced cavitation. The well site geologist will determine when the final development is completed. Pumping at each separate interval shall continue until the turbidity of the discharge water is less than 5 nephelometric turbidity units.

Water chemistry indicators (i.e., $\mathrm{pH}$, temperature, and specific conductivity) shall be measured, evaluated, and recorded during final well development to verify that representative formation water is being produced from the new wells. Well development should continue until the water quality parameters stabilize. When the parameters stabilize, one water sample will be collected and provided to the PNNL POC. Drawdown data will be recorded during well development. Accurate drawdown observations are required for proper flow rate setting of the Redi-Flo3 permanent sampling pump (Grundfos Pumps Corporation, Fresno, California) that will be installed later. After final well development is complete, the depth to bottom of the well bore shall be checked, and, if necessary, excess sediment will be removed by bailing.

A borehole deviation survey using a downhole gyroscope (provided by others) shall be performed on each well following construction and prior to installation of the dedicated sample pump. The field geologist or the FHI designee is responsible for notifying the contractor (currently Duratek Federal Services) responsible for performing the gyroscope survey when it is needed on the drill site. Completion 
of the gyroscope surveys and documentation of survey results shall be performed by the contractor's survey technician with support, as needed, from the drilling contactor to provide access to the well. A survey report shall be delivered as soon as practicable to the PNNL POC.

\subsection{Post-Construction Activities}

A dedicated Redi-Flo3 submersible sample pump, Grundfos Model 5SQE03A-90NE, shall be installed in each well after final well development. The FHI drilling subcontractor shall procure and install each pump. The pump intake shall be installed approximately $10 \mathrm{ft}$ below the water table unless otherwise directed by the PNNL POC. The pump shall be tested after installation to confirm it is operating properly and that water can be pumped to the surface. Redi-Flo3 pumps are shipped from the manufacturer with the check valve installed. Prior to installation, the check valve shall be removed according to the manufacturer's instructions.

No galvanized steel is to be used in permanently installed well construction or pump installation materials. The 0.75 -in. discharge riser shall be made of schedule 40, 304, or 304L stainless steel pipe and couplings secured to the pump support platform assembly using a stainless steel coupling.

The recommended design for a 6-in. diameter pump support platform, manufactured by Instrumentation Northwest, Redmond, Washington (phone 1-800-776-9355 or 1-425-885-3729), is shown in Figure 2. However, for these wells 8-in.-diameter or larger pump support platforms are required and PNNL strongly recommends that the contractor contact the manufacturer to determine if it carries pump support platforms for the larger-diameter casing sizes. If not, a custom platform shall be ordered. On each pump support plate, an aluminum tag shall be attached by a lanyard to the cap of the electrical connector and stamped with pump model and well number. The well support platform and seal shall consist of a stainless steel plate with a 0.25 -in.-thick top plate designed to rest flat on top of the protective well casing with a diameter identical to the specified outside diameter of the schedule 40 protective casing. In the center of the support platform is a 1.065-in.-diameter opening to allow passage of the 1.050-in.-outside diameter of the 0.75-in.-inside diameter stainless steel riser pipe.

The pump riser pipe will be supported using a 1.375-in.-outside diameter stainless steel coupling resting on the upper support plate as shown in Figure 2. Two 1.1-in.-diameter access ports for water level measurements and sensors shall be provided (see Figure 2). Caps shall be provided for all the access ports and the electrical connection.

All submersible electrical cable plugs shall be straight-blade, 15-ampere, 250-volt, 2-pole, 3-wire grounding corrosion-resistant attachment plugs that are Industrial Specification Grade, listed by Underwriters Laboratories, Inc., to federal specifications, and Canadian Standards Association-certified where applicable. The face shall be dead front to comply with National Electrical Code requirements. Wiring means shall be clamp-type back-wiring terminals designed for stranded wire, with separate wells for each conductor, including grounding, identified by colored rings: green (ground), black (hot), and white (neutral). 


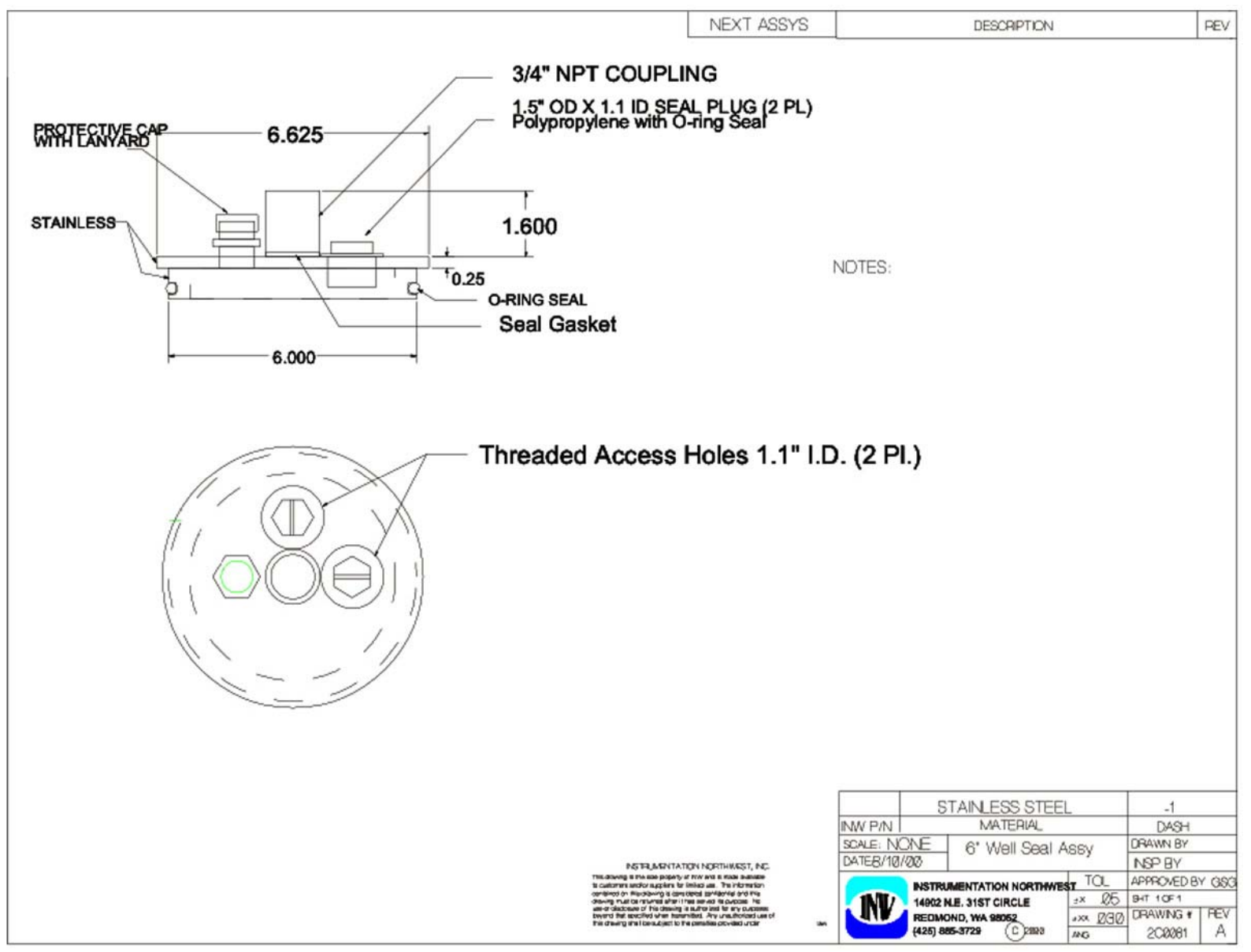

Figure 2. Example Diagram of a 6-Inch-Diameter Support Plate for the Sampling Pump System

A Grundfos SQE-NE Tefzel cable kit shall be installed with the pump. At a minimum, the lead length of the Tefzel cable kit will be equal to the depth to bottom minus the depth to water plus $10 \mathrm{ft}$. This will provide sufficient cable to lower the pump to maximum possible depth and maintain a continuous lead length to a point above the static water level. Standard submersible pump electrical cable shall then be spliced to the Tefzel cable and terminate at the electrical plug on the surface. This standard electrical cable shall be of sufficient length so that the pump can be lowered to the bottom of the screened interval as the water table drops. Extra electrical cable shall be stored between the 8-in. well casing and the protective surface casing, either coiled around the riser or bundled and placed between the riser and protective casings, so that there is minimal interference with sample collection or water table measurements.

Following installation and testing, the electronic controls in the Redi-Flo3 pumps will be programmed to a specific pump rate. PNNL will program the pumps using drawdown data from the previous well development data. The importance of recording accurate and detailed observations by FHI during well development is emphasized. FHI shall provide the well drawdown and recovery data to the PNNL POC following pump installation and allow PNNL well access, if necessary, to adjust the pump rate. 
An inspection of the completed wells shall be made by both FHI and PNNL personnel prior to both FHI and PNNL accepting the wells as complete from the drilling contractor. The inspection is to verify that the wells

- $\quad$ are constructed according to these specifications

- meet the minimum WAC 173-160 well construction requirements

- $\quad$ are sample-ready

- $\quad$ meet standard Hanford Site well construction requirements

Depth to water shall be measured during the well inspections. An incomplete well, or deficiencies or changes from the original design (as outlined in this SOW), will be reviewed, and a determination of closeout actions shall be jointly approved by the contractor and PNNL prior to written acceptance of the well by PNNL. A successful inspection will result in PNNL accepting the wells for monitoring purposes. A copy of the contractor's final well acceptance sheet will be transmitted to the PNNL POC.

FHI shall have the wells surveyed in accordance with Section 9 of this SOW.

\subsection{Waste Management}

Prior to drilling, a waste management plan will be developed identifying specific contaminants of concern for the wells. In addition, if sampling is necessary, FHI will develop a sampling and analysis plan for waste designation sampling.

FHI will give all direction to field personnel for waste packaging directly to the drilling subcontractor and other affected personnel. All miscellaneous waste will be bagged, labeled, and disposed of by FHI in accordance with the appropriate site-specific waste management plan (DOE 2000) which will be provided by PNNL. Decontamination fluid and purgewater will be disposed of as purgewater (either containerized or put directly into a purgewater truck) as directed by the FHI personnel and/or waste transportation specialist.

All waste generated will be returned to ground surface or disposed of at the low-level burial grounds, Environmental Restoration Disposal Facility, or other approved disposal facility as defined by waste management documentation, which shall be prepared by the DOE drilling contractor (currently FHI).

\subsection{Final Well Survey}

FHI will be responsible for the final well surveys. The wells shall be surveyed and a Survey Data Report submitted to the PNNL POC. The final survey is to occur after the permanent sample pump has been installed and no later than approximately 30 days following completion of the wells.

Experienced survey personnel supervised by a licensed land surveyor shall perform the well survey. The center of the survey marker (brass cap) and the center of the protective casing shall be surveyed for 
horizontal coordinates. In addition, the survey marker, the top of the outer protective casing, and the top of the pump landing plate shall be surveyed for elevation. Elevation is to be reported rounded to the nearest $0.001 \mathrm{~m}$, and horizontal coordinates are to be reported to the nearest $0.01 \mathrm{~m}$. The maximum allowable error on leveling is computed as $(12 \mathrm{~mm})(\mathrm{K})^{1 / 2}$, where $\mathrm{K}$ is the horizontal distance of closure in kilometers.

Surveys shall report horizontal position using the Washington State Plane Coordinate System of 1983, South Zone 1991 (WCS83S) in meters. Surveys shall report vertical position (i.e., elevation) using the North American Vertical Datum of 1988 (NAVD88). The Survey Data Report must indicate the horizontal and vertical datum used.

\subsection{Technical Procedures/Specifications}

This section identifies technical procedures/specifications applicable to field activities that FHI shall perform under this SOW. Activities associated with drilling and completing the well and management of waste shall adhere to, at a minimum, the FHI procedures and requirements described below.

\subsection{General Requirements}

Field work for the wells will be conducted in accordance with FHI procedures and FHI blue-sheeted Environmental Restoration Contractor procedures and protocols and the specifications in this SOW. The applicable procedures are discussed in the following sections.

\subsection{Technical Procedures/Specifications}

This section identifies technical procedures/specifications applicable to field activities performed under this SOW. Activities associated with the drilling and installation of these wells and management of waste generated by these activities will adhere to, at a minimum, the following FHI procedures and requirements:

- $\quad$ HNF-PRO-10863, Notebooks and Logbooks

- $\quad$ GPR-EE-01-1.11, Purgewater Management

- $\quad$ GPR-EE-01-3.0, Chain of Custody

- $\quad$ GPR-EE-01-3.1, Sample Packaging and Shipping

- $\quad$ GPR-EE-01-4.0, Soil and Sediment Sampling

- $\quad$ GPR-EE-01-6.2, Field Cleaning and/or Decontamination of Geoprobe and Drilling Equipment

- $\quad$ GPR-EE-01-7.0, Geologic Logging

- $\quad$ GPR-EE-02-14.0, Drilling, Maintaining, Remediating, and Decommissioning Resource Protection Wells, Geoprobe, and Geotechnical Soil Borings 
- $\quad$ Bluesheeted FHI waste management procedures HNF-PRO-15333, HNF-PRO-15334, HNF-PRO15335, HNF-EP-0063, and HNF-EP-0063, as required

- $\quad$ WAC 173-160, Minimum Standards for Construction and Maintenance of Wells

\subsection{Quality Assurance}

FHI shall maintain and follow DOE-approved administrative and technical procedures used by Bechtel Hanford, Inc. (BHI), under the environmental restoration contract. This includes BHI-QA-01, ERC Quality Program, which defines the environmental restoration contractor (ERC) management system to provide quality assurance. BHI-QA-01 provides a quality assurance program designed to meet the requirements of the Tri-Party Agreement (Ecology et al. 1989, as amended), DOE Orders, and state/local regulations. All work performed under this project plan and any work packages that accompany the plan will be performed in compliance with BHI-QA-01 or subsequent and equivalent FHI Quality Program documents.

PNNL will be permitted to conduct quality assurance assessments during the well installation to determine that the requirements in this SOW are fulfilled. If such an assessment is to be done, PNNL will notify FHI 48 hours prior to sending assessment personnel into the field.

The FHI quality management program is implemented for this project via the following BHI manuals:

- $\quad$ BHI-QA-01, ERC Quality Program

- $\quad$ BHI-QA-03, ERC Quality Assurance Program Plans

- $\quad$ BHI-DE-01, Design Engineering Procedures Manual

- $\quad$ BHI-EE-01, Environmental Investigations Procedures

- $\quad$ BHI-EE-02, Environmental Requirements

- $\quad$ BHI-EE-10, Waste Management Plan

- $\quad$ BHI-MA-02, ERC Project Procedures

- $\quad$ BHI-SH-02, Safety and Health Procedures, Vols. 1, 3, and 4

- $\quad$ BHI-SH-05, Industrial Hygiene Work Instructions

\subsection{Health and Safety}

General worker health and safety training requirements, technical procedures, and technical specifications associated with this drilling project are identified in this section. FHI is responsible for, and shall coordinate, project safety and health, radiation screening and protection, waste management, and quality assurance. FHI, PNNL, and/or other contractors performing work at the wellsite shall have the authority to stop work if safety concerns arise. 


\subsection{General Requirements}

All personnel working at the drilling sites addressed by this plan will have completed, at a minimum,

- $\quad$ Occupational Safety and Health Administration Act 40-hour Hazardous Waste Site Worker training program (29 CFR 1910.120)

- $\quad$ Hanford General Employee Training (HGET) required for access to the 100 and 200 Areas

- $\quad$ Radiation Worker II

Work will be performed in accordance with the following procedures:

- HNF-5173, "Project Hanford Management Contract Radiological Control Manual”

- $\quad$ site-specific documents, as applicable:

- health and safety plans

- radiological evaluation/radiation work permits

- activity hazard analysis/job safety analysis

- blue-sheeted site-specific waste management instructions

- $\quad$ HNF-IP procedures

- $\quad$ Central Plateau radiological control procedures

\subsection{Radiological and Chemical Hazard Evaluation}

The wells will be reviewed for radiological risk by the FHI Radiological Control organization. It is desirable that the wells be classified as low risk. If the wells are classified as medium to high risk, the FHI POC will notify the PNNL POC to determine if alternative locations or sampling requirements can be identified.

\subsection{Schedule}

FHI shall coordinate and prepare a schedule to meet drilling requirements identified in this SOW and the attached Well Data Sheet (Appendix A). The two deep characterization wells shall be completed and sample-ready on or before December 15, 2005. The additional two shallow characterization wells shall be sample-ready by no later than January 25, 2006. FHI shall provide a drilling schedule to the PNNL POC two weeks prior to equipment mobilization for drilling.

\subsection{Deliverables}

\subsection{Drilling Contract Review}

FHI shall allow the PNNL POC to review and comment on the request for proposal (RFP) for drilling at least one week prior to putting the RFP out for bid. 


\subsection{State Start Cards}

A copy of the well Start Card notification to the Washington State Department of Ecology shall be provided to the PNNL POC.

\subsection{Project Meetings and Communications}

FHI will conduct meetings as needed during the project to communicate activities to PNNL, DOE, and other interested contractors and regulators. The purposes of the meetings are to state progress, resolve issues and/or conflicts, and conduct other activities. The FHI POC or his designee will contact and brief the PNNL POC daily (via electronic mail or in person) of drilling progress and activities, issues, problems, and schedule status. All field data and activity reports are to be available on request during the project.

\subsection{Final Well Data}

A final data package containing the borehole geologic log, field activity reports, final well number, Survey Data Report, well as-built, well completion log, sieve analysis results, geophysical logs, and well development and pump installation documentation for the well shall be delivered to the PNNL POC within 1 month after completion of the project.

\subsection{Project Completion/Final Well Acceptance}

Before accepting the new wells as sample ready from FHI and/or the drilling contractor, FHI will conduct a final well inspection to enable the PNNL POC, project scientists, and FHI to review and validate completion of the wells. The inspection is to ensure that the wells are constructed according to these specifications, that the wells meet the minimum WAC 173-160 well construction requirements, and that the completed wells meet standard Hanford Site well construction requirements. Depth to water shall be measured during the well inspections. An incomplete well, or deficiencies or changes from the original design (as outlined in this SOW), will be reviewed and a determination of closeout actions will be approved between FHI and PNNL prior to written acceptance of the well by PNNL. A successful inspection will result in PNNL accepting the wells for monitoring purposes. A copy of the contractor's final well acceptance sheet will be transmitted to the PNNL POC.

\subsection{Records Required by WAC 173-160}

FHI shall be responsible for determining that the drilling contractor has completed and submitted the Resource Protection Well Record required by WAC 173-160-420 to the Washington State Department of Ecology on the required well record form. Copies of the well record form shall be submitted to the PNNL POC within 1 month after completion of work. 


\subsection{References}

29 CFR 1910.120. 1999. “Hazardous Waste Operations and Emergency Response.” Occupational Safety and Health Administration, U.S. Department of Labor, Code of Federal Regulations.

Bechtel Hanford, Inc. 2001. "Risk Assessment for Excavation and Well Sites.” Procedure 10.2 in Radiological Control Procedures. BHI-RC-03, Bechtel Hanford, Inc., Richland, Washington.

CERCLA - Comprehensive Environmental Response, Compensation, and Liability Act. 1980. Public Law 96-150, as amended, 94 Stat. 2767, 42 USC 9601 et seq.

DOE-RL. 1990. "Strategy for Handling and Disposing of Purgewater at the Hanford Site, Washington." Letter No. 90-ERB-040, to PT Day, U.S. Environmental Protection Agency, and TL Nord, Washington State Department of Ecology, July 19, 1990, Richland, Washington.

DOE. 2000. Waste Management Plan for the 300-FF-5 Operable Unit. DOE/RL-2000-56, Rev. 1, U.S. Department of Energy, Richland Operations Office, Richland, Washington.

DOE. 2005a. 300-FF-5 Operable Unit Limited Field Investigation Plan. DOE/RL-2005-47, Rev. 0, U.S. Department of Energy, Richland Operations Office, Richland, Washington.

DOE. 2005b. Work Plan for Phase III Feasibility Study 300-FF-5 Operable Unit. DOE/RL-2005-41, Rev. 0, U.S. Department of Energy, Richland Operations Office, Richland, Washington.

Ecology - Washington State Department of Ecology, U.S. Environmental Protection Agency, and U.S. Department of Energy. 1989. Hanford Federal Facility Agreement and Consent Order. Document No. 89-10, as amended, (The Tri-Party Agreement), Olympia, Washington.

EPA. 1996. Record of Decision for the 300-FF-1 and 300-FF-5 Operable Units. U.S. Environmental Protection Agency, Washington State Department of Ecology, and U.S. Department of Energy, Richland Operations Office, Richland, Washington.

NAVD88. 1988. North American Vertical Datum of 1988.

RCRA - Resource Conservation and Recovery Act. 1976. Public Law 94-580, as amended, 90 Stat. 2795, 42 USC 6901 et seq.

WAC 173-160. 1998. "Minimum Standards for Construction and Maintenance of Wells," as amended. Washington Administrative Code, Olympia, Washington.

WAC 173-160-420. 1998. "General Requirements for Construction of Resource Protection Wells," Subpart (10), "Resource protection well and geotechnical soil boring drilling reports.” Washington Administrative Code, Olympia, Washington.

WAC 173-303. 1984. "Dangerous Waste Regulations,” as amended. Washington Administrative Code, Olympia, Washington. 
WAC 173-303-400. 1984. “Interim Status Facility Standards,” as amended. Washington Administrative Code, Olympia, Washington.

WAC 173-303-600. 1984. "Final Facility Standards," as amended. Washington Administrative Code, Olympia, Washington.

Walker TG. 2005. The Groundwater Performance Assessment Project Quality Assurance Plan. PNNL15014, Pacific Northwest National Laboratory, Richland, Washington. 


\section{Appendix A}

\section{Well Data Sheet and Well Staking Plat 300-FF-5 Operable Unit}




\section{Appendix A}

\section{Well Data Sheet and Well Staking Plat 300-FF-5 Operable Unit}

\section{A.1 Data Sheet for Four CERCLA Groundwater Monitoring Wells for 300-FF-5 Operable Unit, FY 2006}

\section{A.1.1 Location}

Two deep characterization boreholes and two shallow characterization boreholes shall be drilled within the 300-FF-5 Operable Unit, in the southeastern portion of the Hanford Site. The four boreholes will be completed as shallow groundwater monitoring wells, based on criteria defined below. The well locations are shown on the attached plat of the 300 Area. Pacific Northwest National Laboratory (PNNL) shall stake the locations. As necessary, ground-penetrating radar (GPR) surveys will be conducted around the staked locations to ensure that no subsurface hazards or drilling obstacles are present near the location stakes. The FHI point of contact (POC) will contact the PNNL POC immediately to determine a replacement location if subsurface obstacles require moving a location. The proposed new wells are located as follows:

- $\quad$ 3LFI-1-1 (CXXXX), 35 feet northeast of Well 399-2-1, southeast of the 316-1 South Process Pond

- $\quad 3 L F I-2-1$ (CXXXX), 10 feet north of decommissioned Well 399-1-19 at the southern end of the now decommissioned 316-5 Process Trenches

- $\quad$ 3LFI-3-1 (CXXXX), 328 feet west of the 316-1 South Process Pond

- $\quad 3 L F I-4-1$ (CXXXX), 40 feet east of the 307 Trench

\section{A.1.2 Approximate Well Depth}

The approximate well depth is as listed in Table A.1. Well identification numbers (Table A.1) correspond to well locations as defined on the well location staking plat (Figure A.1). 
Table A.1. Well ID Number, Location, Proposed Depth, Type, and Screen Length for Fiscal Year 2006 Wells at 300-FF-5 Operable Unit

\begin{tabular}{|c|c|c|c|c|c|}
\hline $\begin{array}{c}\text { Well } \\
\text { Identification } \\
\text { Number/Location }\end{array}$ & $\begin{array}{l}\text { Characterization } \\
\text { Drill Depth (ft) }\end{array}$ & $\begin{array}{c}\text { Completion Design } \\
\text { Type }\end{array}$ & $\begin{array}{l}\text { Estimated } \\
\text { Depth to } \\
\text { Water Table } \\
\text { (ft) }\end{array}$ & Pump Type & $\begin{array}{c}\text { Screen } \\
\text { Length (ft) }\end{array}$ \\
\hline $\begin{array}{l}\text { 3LFI-1-1, 35 ft } \\
\text { northeast of well } \\
\text { 399-2-1 }\end{array}$ & $120 \pm 5$ & $\begin{array}{l}\text { 8-in.-diameter } \\
\text { shallow completion } \\
\text { ( upper } 15 \mathrm{ft} \text { of } \\
\text { aquifer) }\end{array}$ & $35 \pm 5$ & $\begin{array}{l}\text { Redi-Flo3 Model } \\
\text { 5SQE03A-90NE }\end{array}$ & $\begin{array}{l}15 \text { (or as } \\
\text { determined by } \\
\text { PNNL) }\end{array}$ \\
\hline $\begin{array}{l}\text { 3LFI-2-1, 10 } \\
\text { northeast of } \\
\text { decommissioned } \\
\text { well 399-1-19 }\end{array}$ & $115 \pm 5$ & $\begin{array}{l}\text { 8-in.-diameter } \\
\text { shallow completion } \\
\text { ( upper } 15 \mathrm{ft} \text { of } \\
\text { aquifer) }\end{array}$ & $35 \pm 5$ & $\begin{array}{l}\text { Redi-Flo3 Model } \\
\text { 5SQE03A-90NE }\end{array}$ & $\begin{array}{l}15 \text { (or as } \\
\text { determined by } \\
\text { PNNL) }\end{array}$ \\
\hline $\begin{array}{l}\text { 3LFI-3-1, } 328 \mathrm{ft} \\
\text { west of the 316-1 } \\
\text { South Process } \\
\text { Pond }\end{array}$ & $85 \pm 5$ & $\begin{array}{l}\text { 8-in.-diameter, } \\
\text { shallow (upper } 15 \\
\text { ft of aquifer) }\end{array}$ & $50 \pm 10$ & $\begin{array}{l}\text { Redi-Flo3 Model } \\
\text { 5SQE03A-90NE }\end{array}$ & $\begin{array}{l}15 \text { (or as } \\
\text { determined by } \\
\text { PNNL) }\end{array}$ \\
\hline $\begin{array}{l}\text { 3LFI-4-1, 40 ft } \\
\text { east of the } 307 \\
\text { Trench }\end{array}$ & $85 \pm 5$ & $\begin{array}{l}\text { 8-in.-diameter, } \\
\text { shallow (upper } 15 \\
\mathrm{ft} \text { of aquifer) }\end{array}$ & $50 \pm 10$ & $\begin{array}{l}\text { Redi-Flo3 Model } \\
\text { 5SQE03A-90NE }\end{array}$ & $\begin{array}{l}15 \text { (or as } \\
\text { determined by } \\
\text { PNNL) }\end{array}$ \\
\hline
\end{tabular}

\section{A.1.3 Special Instructions}

The final length and placement of the well screens will be decided by the PNNL POC, and the information provided to the FHI POC for completion of the wells. As a default specification, the new wells shall be screened from the water table to about $15 \mathrm{ft}$ below the water table. The anticipated depth to water is $35 \pm 5 \mathrm{ft}$ below ground surface (bgs) in 3LFI-1-1 and 3LFI-2-1 and $50 \pm 10 \mathrm{ft}$ bgs in wells 3LFI3-1 and 3LFI-4-1. Screen placement will be decided based on the following criteria:

- If a maximum concentration of uranium greater than 10 times site background (site background is $\sim 5$ to $8 \mu \mathrm{g} / \mathrm{L}$ ) exists in the upper $15 \mathrm{ft}$ of the uppermost aquifer, then the top of the screen will be placed at the highest measured water table elevation ( $\pm 6.5 \mathrm{ft}$ ) based on historical water level data. If there is a maximum in the concentration of uranium greater than 10 times site background in the drilled part of the aquifer at a depth greater than $15 \mathrm{ft}$, then the completion of the well will be reevaluated at that time. The length of the screen will be based on the thickness of the saturated Hanford formation or $15 \mathrm{ft}$, whichever is greater.

- If there are no maxima in the concentrations of uranium greater than 10 times site background, then the top of a 15-ft screen will be placed at the highest measured water table elevation (based on historical water level data). 


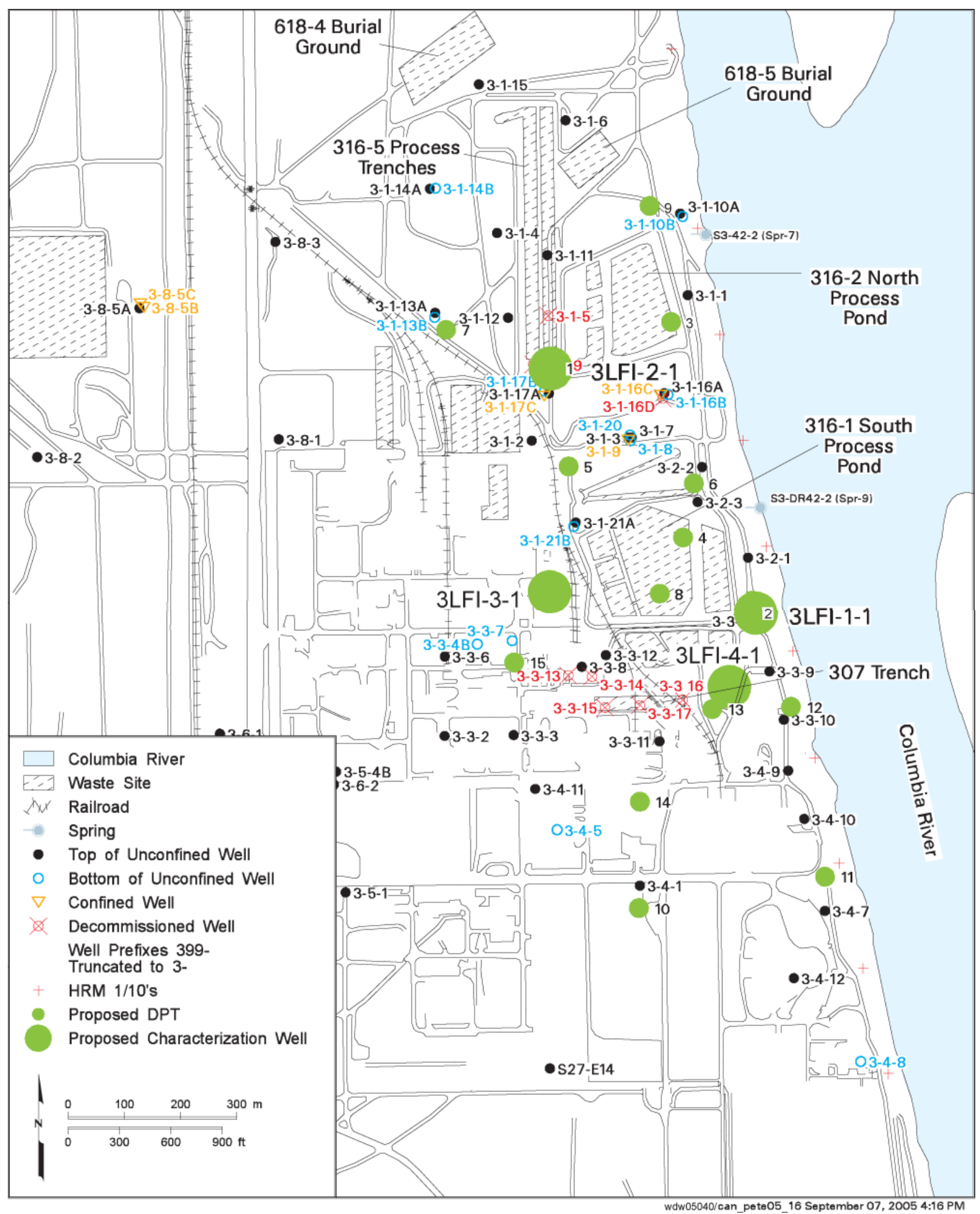

Figure A.1. Proposed New Characterization Wells at 300-FF-5 Operable Unit, 300 Area 
The depth to water shall be measured 1) as soon as possible after encountering the water table, 2) periodically throughout the day, 3) continuously during well development to monitor drawdown, and 4) continuously after well development to monitor recovery. E-tapes shall be used for routine measurements, and a transducer and data logger shall be used during well development. Water levels shall be recorded to the nearest $0.01 \mathrm{ft}$.

\section{A.1.4 Sampling Requirements}

\section{A.1.4.1 General}

Sediment sampling is required during drilling. Sediment samples will be composed of representative grab samples every $5 \mathrm{ft}$ and at changes in lithology or at depths where unusual conditions are encountered (as determined by the field geologist) for lithologic descriptions from surface to total depth. Samples are to be collected in pint or quart glass jars capable of sealing existing moisture in the sample for a reasonable time period. If representative samples cannot be collected (for example, if large particles do not fit in the container, or coring consumes most of the available sample), notes describing the condition of the sample will be put in the geologist's log. A sediment sample will be collected from each sample interval, labeled (well number and depth), and (if appropriate) radiation released. Chip tray samples also are required from the borehole.

In addition to the routine samples described above, 6- to 8-in.-diameter continuous intact core sampling is required during drilling at each location. Larger-diameter core samples are preferred over smaller-diameter core. Core sampling shall commence at ground surface or as soon as possible and continue to total depth. The sampling technique will require at a minimum 1-ft-long rigid Lexan ${ }^{\circledR}$ liners for containing the core and a retaining basket to keep the core from shifting or falling out during retrieval. The core sample liners will be labeled with a continuous arrow pointing toward the shallow end of the liner. The top and bottom liner depths will be included at each end of the liners. Well number, date, depth interval, and liner order (i.e., 1, 2) also will be labeled on the center of each liner. Any void space in the liner will be filled with aluminum foil or other inert material to prevent shifting of the sample. The liners will be capped and taped to seal in any moisture and prevent loss of sample material. The core will be stored in coolers with frozen blue ice. Chain-of-custody forms are required for the core samples.

Continuous geologic descriptions of drill cuttings shall be recorded as a continuous borehole log. The log will include descriptions of the following:

- $\quad$ drilling conditions and changes in drilling conditions (e.g., drilling method, drill rate, addition of fluids, heaving sand)

- $\quad$ depths and types of all collected samples

- $\quad$ lithologic descriptions of sediments

- $\quad$ results of radiation and chemical monitoring of sediments

- $\quad$ water level

Subsurface geophysical logging and measurements of spectral gamma and neutron moisture are required in these boreholes. Geophysical logging will be conducted by others prior to downsizing temporary casing strings (does not include surface pipe) and at borehole total depth for identification of 
contaminants, site characterization, stratigraphic correlation, and selection of final screen placement. It is recommended that casing greater than $10 \mathrm{in}$. in diameter or more than $0.5 \mathrm{in}$. thick not be used at depths greater than $10 \mathrm{ft}$. Anomalous or unusual readings may be re-logged as necessary.

\section{A.1.4.2 Vadose Sampling}

Grab samples and continuous core samples as specified in Section A.1.4.1 above are required throughout the vadose zone. If sample material is not available for collection, the intervals not collected shall be noted so on the geologist borehole log.

\section{A.1.4.3 Saturated (aquifer) Sampling}

Groundwater sampling will be required during drilling of the four boreholes. Depth-discrete water samples shall be collected from the boreholes during drilling beneath the water table. Approximately 10 depth-discrete groundwater samples will be recovered during drilling in each of the two deep characterization boreholes and 5 samples will be recovered during drilling in each of the two shallower characterization boreholes. For the two deep characterization wells this sampling shall occur immediately below the water table (or when the borehole is deep enough to allow sampling to be accomplished) and at 5, 10, 15, 20, 30, 40, 50, and $60 \mathrm{ft}$ below the water table (or just above the Ringold Lower Mud unit). Sampling in the two shallower wells will be at the same depths specified above but only continue until the proposed total depth is reached. PNNL shall provide the sample bottle sets (and/or containers) to FHI prior to well startup.

Sampling shall be accomplished as follows. At each specified sample interval, drilling will be stopped, the borehole cleaned of all cuttings, a temporary $10 \mathrm{ft}$ long screen and packer installed to isolate the interval, and the drill casing pulled back approximately 1 to $5 \mathrm{ft}$ to enhance groundwater flow into the borehole. A submersible pump or other suitable sampling device shall be used to collect the groundwater samples. The pump will be installed to allow continuous pumping of groundwater from the zone to be sampled. Specific conductivity, $\mathrm{pH}$, temperature, and water level drawdown shall be monitored and recorded on location during pumping. All field sampling equipment, transducers, and data loggers are to be provided by the drilling contractor or FHI. Sampling will begin when the field parameters stabilize, or after 5 minutes of purging, whichever is first. If during the first depth-discrete water sampling episode the saturated interval within the drilled borehole does not yield adequate water (i.e., as estimated by the field geologist based on available drilling, water level, and sampling information), the FHI POC will notify the PNNL POC immediately to determine if additional drilling is necessary to increase water production. Immediately upon completion of sampling, the FHI POC shall contact the PNNL POC, who will retrieve the samples for delivery to the laboratory.

FHI shall coordinate collection of the requested water sample(s) and deliver them to the PNNL POC for rapid analysis.

Two sediment grab samples will be collected from each borehole at the top and bottom depths of the screened interval and used for sieving for confirmation of the screen slot size. Sieving shall be done by FHI and follow appropriate FHI procedures. 


\section{A.1.4.4 Aquifer (slug) Testing}

Depth-discrete slug testing shall be conducted in the boreholes at approximately 10, 20, 30, and $60 \mathrm{ft}$ (top of Lower Mud unit) below the water table (or 45, 55, 65, and $110 \mathrm{ft}$ bgs). Testing in the shallower boreholes will consist of three tests at 10, 20, and $30 \mathrm{ft}$ below the water table (or 60, 70, and $80 \mathrm{ft}$ bgs). The slug tests shall be performed after the depth-discrete aquifer sample has been collected for the specified depth. Slug testing will be accomplished as follows. When the specified depth interval has been reached, a 10-ft-long well-screen/inflatable packer assembly (packer located immediately above the well screen) will be installed to the bottom of the borehole. The drill casing will then be retracted $\sim 5 \mathrm{ft}$ and the packer inflated to isolate the test interval/well-screen section for hydrologic testing. Multi-stress pneumatic or mechanical (slugging rod) slug tests will be conducted under the supervision of PNNL personnel to characterize the exposed test/depth interval. After this initial characterization, the packer will be deflated and the drill casing retracted an additional $5 \mathrm{ft}$. The packer will be re-inflated, creating an isolated overlapping 10-ft test/depth interval for detailed multi-stress slug test characterization. This characterization approach will provide the vertical distribution of hydraulic conductivity within the upper $30 \mathrm{ft}$ of the unconfined aquifer, based on 5-ft test characterization lengths. Because lower permeability conditions are anticipated for the bottom test interval (top of the Lower Mud unit), a single 10-ft test/depth interval characterization will be performed.

\section{A.1.5 Construction Requirements}

Well casings and screens shall be composed of the same stainless steel alloy, either 304 or 316. Stainless steel screens shall consist of V-wire continuous wire wrap well screen to prevent clogging. The screen surface wire shall be helically wrapped over a circular array of internal rods and bonded using electrical resistance welding to achieve tensile weld strength of at least $100 \mathrm{lb}$ at each wire and rod juncture.

Stainless steel screens will be required for completing the wells. Screen shall be 20-slot screen and the filter pack composed of 10- to 20-mesh silica sand. Field sieve analyses will be done on grab samples taken from the top and bottom of the proposed screen interval for the borehole. Well completion will not begin until the screen slot size and filter pack size are confirmed by sieving the field samples. All sieving shall follow PNNL ${ }^{\text {(a) }}$ or equivalent FHI procedures. If field sieve analyses dictate a screen slot and filter pack of different size than that specified in this SOW, the PNNL POC shall confirm the alternative screen and filter pack. Contractors will be responsible for procuring the appropriate screen. The screens shall be $15 \mathrm{ft}$ in length unless otherwise specified by the PNNL POC. Bentonite well seals shall be completed in such a manner as to isolate the seal from leaking or migrating into the saturated zone and screen interval. FHI shall determine the placement depths and type of sealing materials to be used during the construction. The well construction shall meet the WAC 173-160 requirements.

Redi-Flo3 Model 5SQE03A-90NE submersible pumps are required in the wells. Any additional sampling requirements and changes in the well design for the boreholes will be addressed in future addenda to this Data Sheet.

(a) PNNL. 1999. Procedures for Groundwater Investigations. PNL-MA-567, Pacific Northwest National Laboratory, Hanford Site Groundwater Monitoring Project, Richland, Washington. 


\section{A.1.6 Applicable Documents}

DOE. 2002. Waste Management Plan for the 300-FF-5 Operable Unit. DOE/RL-2000-56, Rev. 1, April 2002. U.S. Department of Energy, Richland, Washington.

DOE. 2002. Operation and Maintenance Plan for the 300-FF-5 Operable Unit. DOE/RL-95-73, Rev. 1, May 2002. Prepared by CH2M HILL Hanford, Inc., for the U.S. Department of Energy, Richland, Washington. 


\section{Appendix B}

Field Geologist Qualifications 


\section{Appendix B}

\section{Field Geologist Qualifications}

\section{B.1 Purpose}

This appendix provides the minimum field (wellsite) geologist qualifications for personnel performing well logging under this statement of work (SOW).

\section{B.2 Minimum Qualifications}

The candidate should have at least a Bachelor of Science degree in geology or geologic engineering, with advanced degrees preferred. The candidate should have a minimum of 1 year experience studying the geology of the Hanford Site and be licensed as a Washington State Geologist. The candidate must also have at least two years well logging experience at the Hanford Site; this experience should include correlation of soil samples. In particular, the candidate is to have specific knowledge of and experience in describing the geology beneath the Hanford Site and have reviewed the new data obtained from recently drilled wells in the area. The candidate will be expected to identify and determine subtle changes in lithology including the presence of clastic dikes, paleosols, caliche zones, and other fine strata, dependent on the quality of the sediments and cuttings.

If the candidate does not meet the minimum qualifications, he or she must be under the supervision of a qualified and licensed geologist as described above. 


\section{Distribution}

No. of

Copies

ONSITE

3 DOE - Richland Operations Office

KM Thompson

DOE Reading Room (2)

2 Fluor Hanford, Inc.

JV Borghese

C Wright
No. of

Copies

10 Pacific Northwest National Laboratory

$\begin{array}{lr}\text { DG Horton } & \text { K6-75 } \\ \text { SP Luttrell } & \text { K6-96 } \\ \text { TG Naymik } & \text { K6-96 } \\ \text { MJ Nimmons } & \text { K6-96 } \\ \text { RE Peterson } & \text { K6-75 } \\ \text { EC Thornton } & \text { K6-96 } \\ \text { TG Walker } & \text { J2-56 } \\ \text { BA Williams } & \text { K6-75 } \\ \text { Hanford Technical Library (2) } & \text { P8-55 }\end{array}$

